\title{
Representasi Sensualitas Perempuan dalam Iklan AXE Effect Call Me versi
}

\section{Sauce}

\author{
Hamidah Nur Fitriani \\ Program Studi Ilmu Komunikasi, Universitas Muhammadiyah Yogyakarta, Indonesia \\ Hamidah.nur.isip19@mail.umy.ac.id \\ Muhammad Raihan Herdiansyah \\ Program Studi Ilmu Komunikasi, Universitas Muhammadiyah Yogyakarta, Indonesia \\ Raihan.h.isip19@mail.umy.ac.id \\ Najmi Sai'dah \\ Program Studi Ilmu Komunikasi, Universitas Muhammadiyah Yogyakarta, Indonesia \\ Najmi.saidah.isip19@mail.umy.ac.id \\ Diserahkan: 28 Mei 2021; Direvisi: 12 Juni 2021; Diterima: 14 Juni 2021
}

\begin{abstract}
Female sensuality in this era is often used in commercial advertisements with the aim of increasing audience attractiveness. The Axe Effect Call Me Sauce ad discussed in this journal is an example of an advertisement that shows how an advertisement uses female sensuality as an element to attract the attention of its audience. This study aims to explore the sensuality of women in Sauce's version of the Axe Effect Call Me advertisement, which shows the sensual objectification of women's bodies. This research was conducted using the semiotic method by analyzing objects through the signs displayed by Asmirandah as a woman in this advertisement. The delivery of information in the advertisement played by Asmirandah includes sensual movements such as biting the lip, besides that it is accompanied by supporting attributes in the form of using sexy clothes that contain sensual meaning and seductive body language to strengthen the impression of sensuality in this advertisement. The results of the research show that this advertisement displays exploitation of women's bodies, the sensuality movement displayed by women to seduce men shows that women are used as objects of view for men. This is in line with the number of advertisements featuring female models to be used as objects of sale and purchase. Female sensuality also directs stereotypes of women as sexual objects.
\end{abstract}

Keywords: Exploitation, Women, Sensuality

\section{Abstrak}

Sensualitas perempuan pada era ini seringkali dimanfaatkan dalam iklan-iklan komersil dengan tujuan untuk meningkatkan daya tarik audiens. Iklan Axe Effect Call Me Sauce yang dibahas dalam jurnal ini merupakan contoh iklan yang menunjukan bagaimana sebuah iklan menggunakan sensualitas perempuan sebagai elemen untuk menarik perhatian penontonnya. Penelitian ini bertujuan untuk mengulik tentang sensualitas perempuan dalam iklan Axe Effect Call Me versi Sauce yang memperlihatkan obyektifikasi sensual dari tubuh perempuan. Penelitian ini dilakukan dengan menggunakan metode semiotika dengan menganalisis objek melalui tanda yang ditampilkan oleh Asmirandah sebagai perempuan dalam iklan ini. Penyampaian informasi pada iklan yang diperankan oleh Asmirandah menyertakan gerakan yang sensual seperti menggigit bibir, selain itu disertai juga dengan atribut pendukung berupa penggunaan pakaian seksi yang mengandung makna sensual dan bahasa tubuh yang menggoda guna memperkuat kesan sensualitas dalam iklan ini. Hasil penelitian menunjukan bahwa pada iklan ini menampilkan eksploitasi terhadap tubuh perempuan, gerakan sensualitas yang ditampilkan oleh perempuan untuk menggoda laki-laki menunjukan bahwa perempuan dijadikan sebagai objek pandangan bagi kaum laki-laki. Hal ini selaras dengan banyaknya iklan yang menampilkan model perempuan untuk dijadikan objek jual-beli. Sensualitas perempuan juga mengarahkan stereotip perempuan sebagai objek seksual.

Kata Kunci: Eksploitasi, Perempuan, Sensualitas 


\section{PENDAHULUAN}

Iklan merupakan salah satu bentuk komunikasi massa yang bertujuan menyampaikan informasi mengenai suatu produk ataupun jasa dan dikemas dalam bentuk konten yang menarik agar mencapai target pasar yang diharapkan. Konten yang diproduksi dalam iklan tentu memiliki 'genre' yang berbedabeda, tergantung produk/jasa yang ditawarkan. Selain konsep, talent yang ada pada iklan juga mempengaruhi taste iklan tersebut. Saat ini, pemilihan talent yang ada pada iklan di beberapa media massa dinilai masih banyak yang kurang tepat, khususnya dalam hal gender. Contoh iklan yang dinilai kurang sesuai dalam hal konsep yang direpresentasikan dengan produk yang dijual yakni iklan AXE Effect-Call Me versi Sauce.

Produk AXE yang diproduksi oleh Unilever merupakan produk wewangian dengan target pasar lakilaki dewasa. Pada iklan AXE Effect-Call Me versi Sauce, terdapat talent laki-laki dan perempuan dewasa, dengan konsep wanita dewasa tersebut terpikat oleh laki-laki yang sudah memakai AXE, namun ditunjukkan dengan gerakan sensual. Hal tersebut dinilai oleh beberapa masyarakat kurang sesuai dengan norma dan etika yang berlaku.

Tujuan dari penelitian ini yaitu membahas tentang sensualitas perempuan dalam iklan AXE Effect Call Me versi Sauce yang memperlihatkan obyektifikasi sensual dari tubuh perempuan. Contoh yang jelas dari objektifikasi sensual perempuan dalam iklan AXE ini yaitu menampilkan model yang menggunakan pakaian minim dengan gerakan-gerakan sensual seperti gerakan tangan ketika memegang saus, kedipan mata, dan gerakan pada bibir yang terkesan menggoda. Diperlihatkan bahwa citra perempuan hanyalah sebagai objek pemuas laki-laki dan perempuan digambarkan sebagai penyampai pesan dan kesan untuk meningkatkan daya jual produk AXE. Keberadaan perempuan yang sensual di media massa semakin menguatkan stereotip negatif perempuan di masyarakat yang mana digambarkan sebagai objek fetish (sesuatu yang selalu menjadi kenangan bagi kaum laki-laki).

Beberapa penelitian terdahulu terhadap adanya sensualitas dalam iklan dapat ditelaah sebagai berikut. Pertama, penelitian yang dilakukan oleh Raturahmi \& Wanty, penelitiannya membahas tentang representasi sensualitas perempuan dalam iklan AXE versi Kencan Bidadari terkait ikon yaitu berupa representasi sensualitas perempuan yang negatif. Dalam iklan ini digambarkan ikon-ikon yang menunjukan eksploitasi terhadap tubuh perempuan. Perempuan hanya dijadikan sebagai objek pandangan bagi kaum laki-laki (Raturahmi \& Wanty, 2015).

Kedua, penelitian yang dilakukan oleh Irafani, Ramaswati, dan Ade yang berkisar tentang representasi perempuan dalam iklan Susu Jahe Sido Muncul versi Sido Susu. Penelitian tersebut menemukan bahwa melalui bagian - bagian tubuh yang dimiliki oleh perempuan, dijadikan oleh pengiklan sebagai objek iklan karena dianggap sebagai titik penarik perhatian. Tubuh perempuan adalah titik yang paling rentan dan banyak mengalami eksploitasi dalam iklan Susu Jahe Sido Muncul versi Sido Susu. Gesture juga berpengaruh besar dalam mengekspresikan visual untuk menarik perhatian khalayak. Mengedipkan mata dan mengigit bagian bawah bibir yang menimbulkan ketertarikan sensual karena seolah ingin menggoda khalayak yang menonton iklan tersebut. Representasi perempuan yang dilakukan oleh pembuat iklan, hanya menunjukkan perempuan dari sisi sensualitas (Nyoman et al., 1992).

Ketiga, penelitian yang dilakukan oleh Ilma dan Ajeng tentang penggunaan model iklan dalam iklan Cat Avian versi Awas Cat Basah, dimana terdapat perempuan cantik yang membuat normalisasi pada masyarakat bagaimana definisi perempuan ideal dan sempurna. Tidak hanya itu, penelitian tersebut juga membahas media yang selalu menampilkan perempuan tidak hanya dinilai dari kecantikannya saja tetapi juga sebagai objek pemuas laki-laki. Penelitian itu menemukan bahwa perempuan seringkali dinilai rendah karena hanya menjadi model dalam iklan yang memiliki target laki-laki seperti rokok, parfum, kopi, cat, obat-obatan, dan lainnya. Penelitian ini menarik karena menjelaskan bagaimana posisi laki-laki 
di dalam iklan tersebut dianggap objek aktif sedangkan perempuan dianggap objek pasif (Madina \& Kumala, 2020). Berbeda dengan ketiga penelitian di atas yang meneliti AXE versi Kencan Bidadari, Susu Jahe Sido Muncul, dan Cat Avian versi Awas Cat Basah, penelitian ini berfokus pada representasi sensualitas perempuan dalam iklan AXE Effect Call Me versi Sauce. Dengan demikian penelitian ini memiliki obyek kajian yang berbeda dengan penelitian terdahulu.

\section{KAJIAN PUSTAKA}

\section{REPRESENTASI}

Stuart Hall dalam buku Representation: Cultural Representation and Signifying Practice mengemukakan adanya dua sistem representasi. Pertama, mental representation, yaitu "Makna bergantung pada konsep dan gambaran yang terbentuk dalam pikiran kita yang memungkinkan kita untuk merujuk pada hal-hal baik di dalam maupun di luar kepala kita”. Kedua, makna yang bergantung pada susunan penyampaian antara pemikiran dengan sebuah tanda maupun bahasa yang menggambarkan konsep-konsep tersebut (Hall, 2003).

Chris Barker dalam buku The Sage Dictionary of Cultural Studies menjelaskan bahwa representasi adalah serangkaian proses penandaan atau penggambaran suatu objek atau kejadian. Dalam kata lain, representasi merupakan tindakan simbolisme. Sedangkan menurut Jhon Fiskey dalam bukunya, representasi adalah suatu proses menciptakan tanda diri untuk mendapatkan makna tertentu. Representasi adalah proses menempatkan ke dalam bentuk yang konkret yaitu penanda yang berbeda. Namun dalam hal lain representasi diartikan sebagai cara untuk menyampaikan makna pesan yang tertanam dan yang mendasar. Bagaimana perempuan direpresentasikan dalam sebuah iklan dapat dilihat untuk menyampaikan baik sikap pembuat iklan terhadap perempuan, maupun cara perempuan secara umum dipandang, dipahami, atau dikenal dalam konteks tertentu, yang mana perempuan digambarkan dalam sebuah iklan (Alva Orlandini, 2003).

\section{IKLAN}

Periklanan sebagai kata dasar "iklan” berangkat dari bahasa Arab I'lan, kemudian dilafalkan oleh orang Indonesia dengan sebutan iklan. Iklan atau advertising dalam bahasa Inggris berasal dari bahasa latin yaitu advertere yang berarti mengalihkan perhatian, sehingga advertising dapat diartikan sebagai sesuatu yang dapat mengalihkan perhatian khalayak terhadap sesuatu. Maka inti dari periklanan terletak pada bagaimana usaha mengalihkan khalayak agar memperhatikan pada sesuatu yang ingin menjadi tujuan kita. Banyak definisi periklanan, beberapa mengatakan bahwa inti dari periklanan adalah mengumumkan sesuatu dengan menciptakan kesadaran dalam benak khalayak (Zein, 2015).

Menurut Institute if Practitioners in Advertising (IPA) menyebutkan bahwa periklanan merupakan suatu pesan penjualan yang sepersuasif mungkin kepada calon pembeli yang paling tepat atas suatu produk berupa barang atau jasa tertentu dengan biaya yang semurah-murahnya (Zein, dikutip dalam Santosa, 2002). Dalam pengertian tersebut dapat dipahami bahwa ciri khas iklan adalah tidak hanya mengendalikan perhatian saja namun yang paling penting adalah bagaimana proses pengalihan perhatian tersebut merujuk pada gaya persuatif.

Penggunaan model perempuan dalam iklan merupakan salah satu bentuk proses pengalihan perhatian karena perempuan dalam iklan menjadi hal yang sangat menjual. Bagi produk pria, kehadiran perempuan merupakan salah satu bentuk pemikat untuk meningkatkan daya tarik dari produk itu sendiri. Sementara bila target pasarnya perempuan, kehadiran perempuan merupakan bentuk aktualisasi yang mewakili jati diri setiap perempuan. Begitu besarnya pengaruh perempuan dalam iklan sebuah produk tidak dapat dihindari dari kemungkinan terjadinya hal-hal yang merugikan kaum perempuan, di mana perempuan 
dijadikan sebagai obyek iklan yang mengarah ke rangsangan tubuh sehingga terjadi bad taste advertising. Tipologi citra media mengenai perempuan di berbagai media mulai dari berita hingga iklan, menunjukan gambaran perempuan sebagai objek dan sebagai tanda negatif pada budaya yang didominasi laki-laki (Scott, 1997).

Iklan pada dasarnya mengikuti bagaimana tujuan-tujuan promosi dan pemasaran yang telah dibuat. Suharko mengungkapkan bahwa melalui iklan, kelompok-kelompok pemasar komoditas menginterpretasikan dan mensosialisasikan nilai guna dari suatu komoditas, dan memproyeksikannya ke dalam lingkup pasar global. Karena itu iklan merupakan bagian penting dari strategi pemasaran komoditas (Wibowo, 2013). Pesan iklan yang dekat dengan konsumen tentu akan lebih diterima oleh konsumen. Iklan dalam konstruksi pesannya berusaha menghadirkan figure-figur tertentu yang dekat dengan konsumen. Lebih tepatnya iklan berusaha menggambarkan konstruksi pasar yang dibidik olehnya.

Melalui iklan, citra mengenai kelompok-kelompok masyarakat tersebut dibentuk, didiktekan, dan dikonstruksikan ke dalam bangunan kesadaran yang bermuara pada bujukan untuk mengkonsumsi suatu komoditas. Iklan berusaha merepresentasikan kenyataan yang hidup dalam masyarakat melalui simbolsimbol tertentu, sehingga mampu menimbulkan impresi dalam benak konsumen bahwa citra produk yang ditampilkan adalah juga bagian dari kesadaran budayanya (Wibowo, dikutip dalam Suharko). Untuk itu iklan berusaha mengkonstruksi suatu tampilan-tampilan yang dekat dengan kesadaran budaya konsumen menggunakan sejumlah teknik manipulasi sehingga terkonstruksi suatu relitas tertentu.

\section{METODE PENELITIAN}

Penelitian ini berupaya membahas permasalahan tentang representasi sensualitas perempuan dalam iklan Axe Effect Call Me versi Sauce, dan untuk memperoleh jawaban dari rumusan masalah dalam penelitian ini, digunakan metode semiotika. Semiotika merupakan teori bahasa yang dikemukakan oleh Ferdinand de Saussure dalam buku yang berjudul Linguistics Course in General (pertama kali diterbitkan pada tahun 1916). Saussure menolak pandangan bahwa bahasa hanya mencerminkan kenyataan dan sebaliknya menyarankan bahwa bahasa bekerja dalam sistemnya sendiri. Sistem yang dimaksud yaitu bahwa bahasa menciptakan makna yang tidak dapat berkembang secara alami atau unik.

Saussure mengatakan hal ini sebagai pendekatan semiologi, yang berarti studi tentang tanda, tetapi kita akan menggunakan istilah yang lebih umum yang dikenal sebagai semiotika. Tanda (kata) seperti 'tikus', misalnya, memiliki dua sifat: suara dan gagasan. Tetapi tidak ada hubungan antara suara dan gagasan tersebut, jadi 'pilihan suara tertentu gunanya untuk menjelaskan gagasan yang ada'. Saussure mengatakan bahwa tanda bekerja sebagai suatu sistem, tanda-tanda (yaitu kata-kata) yang membentuk suatu bahasa mampu menjelaskan berbagai ide secara tepat karena setiap tanda memiliki perbedaan. Maksudnya adalah 'Bahasa merupakan sistem istilah yang saling bergantung dimana nilai setiap istilah dihasilkan dari kehadiran orang lain. Jadi bahasa tersusun melalui perbedaan dan ide yang berbeda bergantung pada suara yang berbeda, atau 'perbedaan intonasi yang memungkinkan terjadi perbedaan dari satu kata dengan yang lainnya, karena perbedaan membawa makna' (Laughey, 2007).

Dengan demikian, semiotika membahas seputar studi tentang tanda dalam teks. Tanda (sign) mencakup dua aspek, yaitu penanda (signifiant) dan petanda (signified). Penanda dapat dipahami sebagai bentuk/wujud fisik. Penanda dapat berupa bunyi, gambar, huruf, visual dan sejenisnya. Sedangkan petanda merupakan konsep dari apa yang ditandai. Hubungan antara keduanya bersifat "diada-adakan" (arbitrary), yang berarti tidak ada relasi yang sifatnya alamiah antara penanda dan petanda. Dengan demikian semiotika adalah sebuah relasi tripartit, yakni tanda (sign) yang merupakan gabungan dari penanda (signifier) dan petanda (signified) (Hartley, 2003). Pandangan Saussure kemudian dikembangkan 
oleh Roland Barthes. Oleh Barthes, gagasan makna denotatif atau pemaknaan di tingkat primer (primary signification) dikaji lebih lanjut. Barthes menyebutkan bahwa ada makna lain yang justru bermain pada level yang lebih mendalam, yakni pada level konotasi atau pemaknaan sekunder (secondary signification).

Secara operasional, dalam penelitian ini semiotika dipraktikan dengan cara melakukan kajian terhadap tanda-tanda yang terdapat dalam iklan Axe Effect Call Me versi Sauce. Iklan Axe Effect Call Me yang diteliti ditempatkan sebagai teks yang merupakan rajutan dari berbagai tanda. Tanda-tanda yang ada baik dalam bentuk gambar, tulisan, maupun suara diambil dari shoot dan scene yang ada didalam iklan Axe Effect Call Me. Pada tahap hasil penelitian, peneliti akan menyampaikan pemaknaan secara denotatif dan konotatif, yang kemudian dilanjutkan dengan pembahasan yang menganalisis temuan penelitian dengan intertekstualitas dengan berbagai teori yang relevan.

\section{HASIL DAN PEMBAHASAN}

HASIL

Bagian ini memaparkan hasil dengan menampilkan pemaknaan iklan Axe Effect Call Me versi Sauce secara denotasi (primary signification) dan konotasi (secondary signification).
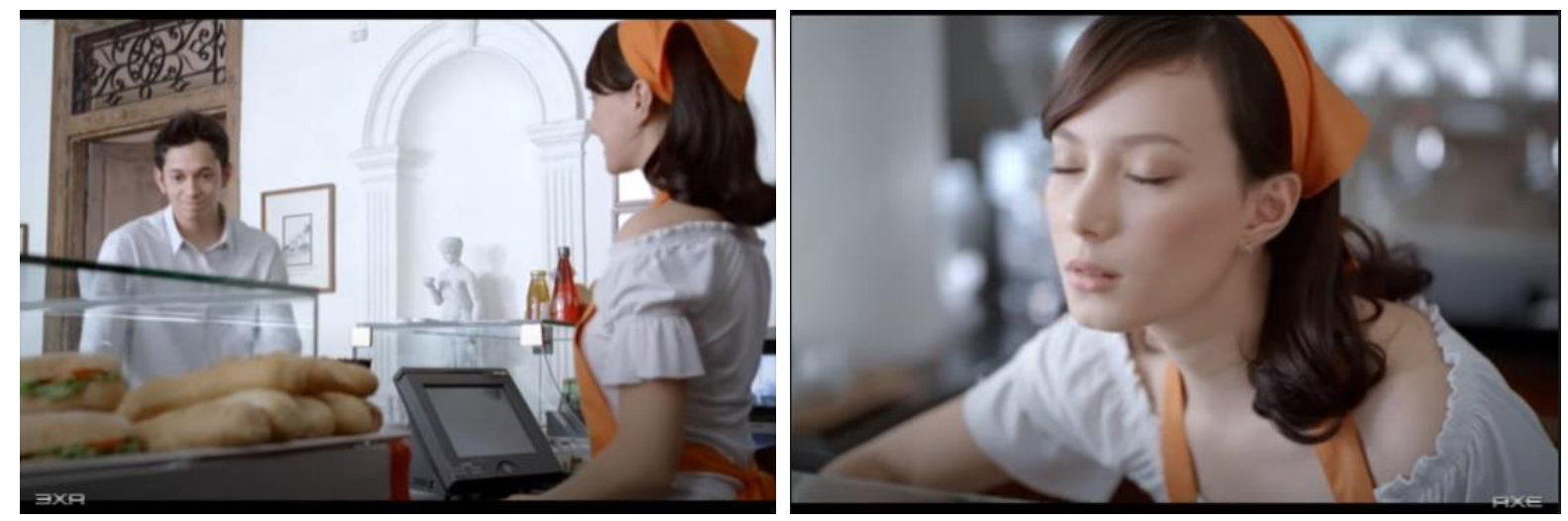

Gambar 1. Iklan Axe Effect Call Me versi Sauce

Makna Denotasi, penanda pada gambar di atas adalah seorang perempuan berpakaian putih dengan celemek oranye. Perempuan tersebut merupakan penjaga kasir yang memiliki kulit putih mulus, beramput panjang, dan bertubuh langsing yang dilengkapi dengan pakaian yang memiliki belahan dada yang rendah.

Makna Konotasi, perempuan cantik adalah perempuan yang berkulit putih bersih dengan tubuh yang langsing. Perempuan pada iklan Axe Call Me Sauce ini memakai pakaian berwarna putih yang mempertegas kebersihan kulit perempuan tersebut. Rambut hitam tergerai seakan-akan menandakan rambut yang bagus dan sehat sebagai gambaran rambut idaman semua perempuan. Perempuan ini juga memiliki tubuh yang langsing yang dianggap sebagai tubuh ideal perempuan. Semua elemen yang ada pada perempuan pada iklan ini menandakan gambaran perempuan cantik dan sempurna yang didambadambakan lelaki.

Mitos, perempuan dalam pandangan laki- laki adalah sebagai objek seksual. Perempuan dihadirkan dalam media, namun tak lain hanya sebagai objek seksual bagi laki-laki (Tuchman, 1979). Perempuan seolah-olah dianggap rendah dan tidak memiliki nilai pada media. Hal ini dikarenakan banyak media yang memanfaatkan tubuh perempuan untuk mengundang daya tarik. Perempuan dituntut untuk berpenampilan sempurna dalam artian mempunyai tubuh langsing, rambut panjang, dan wajah putih cantik. Dalam hal ini, jelas media memperlihatkan bagaimana cara pandang laki-laki terhadap perempuan. 

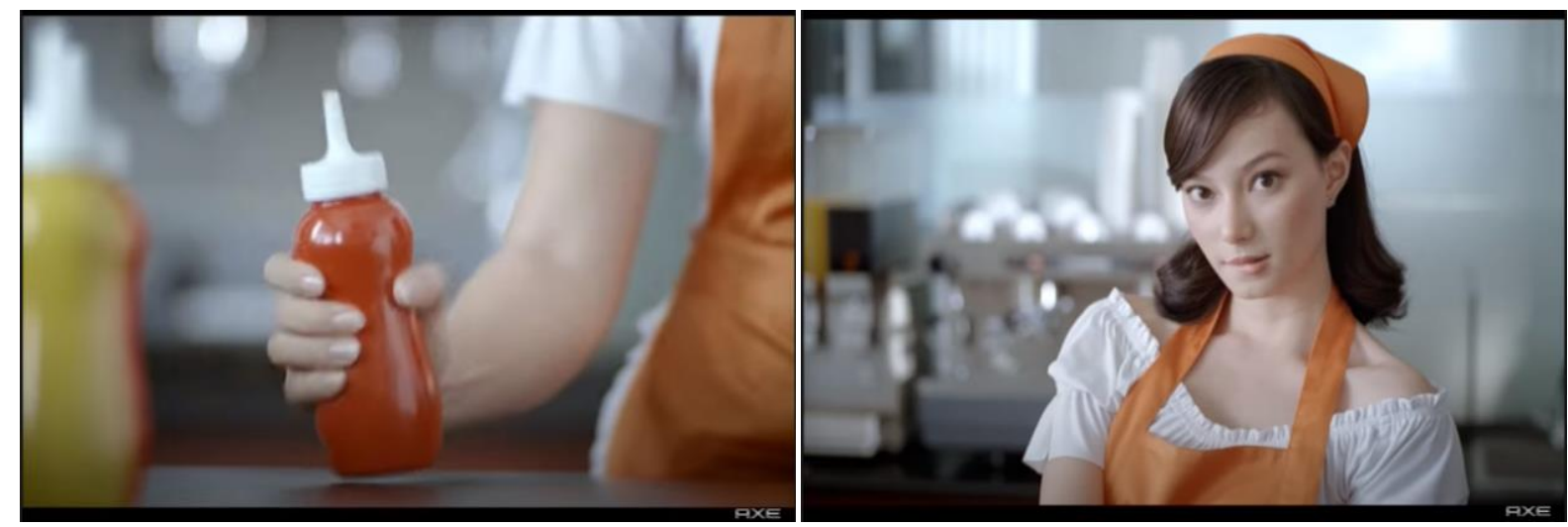

Gambar 2. Iklan Axe Effect Call Me versi Sauce

Makna Denotasi, penanda pada gambar 2 di atas adalah tatapan tajam, gigitan bibir dan tangan yang memegang botol saos. Ketika perempuan itu memegang botol saos seolah-olah memperlihatkan tatapan penuh gairah, hal itu terlihat dari tatapan tajam dan gigitan bibir pada perempuan tersebut.

Makna Konotasi, peran sensual menjadi daya tarik laki-laki. Pada gambar diatas memperlihatkan perempuan yang menampilkan ekspresi, sikap, tingkah laku yang menawarkan sensualitas/seksualitas. Dapat dilihat ekspresi dan tingkah laku perempuan saat memegang botol dan gigitan bibir dengan tatapan yang tajam yang memperlihatkan ketertarikan perempuan tersebut dengan wangi (Parfum Axe) laki-laki tersebut. Dengan begitu, tidak menutup kemungkinan hal tersebut dapat memicu imajinasi seksual pada laki-laki.

Mitos, bahwa daya tarik seksual mempunyai peran-peran potensial. Peran seksual pada iklan bertindak sebagai daya tarik perhatian sekaligus mempertahankan perhatian untuk waktu lebih lama sering kali ditunjukkan dengan model yang menarik dengan pose merangsang. Daya tarik seksual menghasilkan ingatan yang lebih baik apabila pelaksanaan periklanan mempunyai hubungan yang tepat dengan produk yang diiklankan. Proses komodifikasi ini terlihat dari tubuh perempuan yang dieksploitasi sedemikian rupa dan dijabarkan baik secara fisik maupun nonfisik. Ekploitasi secara fisik ditunjukkan dengan cara mengekspose beberapa bagian tubuh seperti bibir, pundak, dan bahasa tubuh yang menunjang terbentuknya image sexy. Sedangkan secara nonfisik terlihat dengan menampilkan perempuan dalam berbagai karakter seperti mudah tergoda, seksi, dan agresif (Pah, 2018).

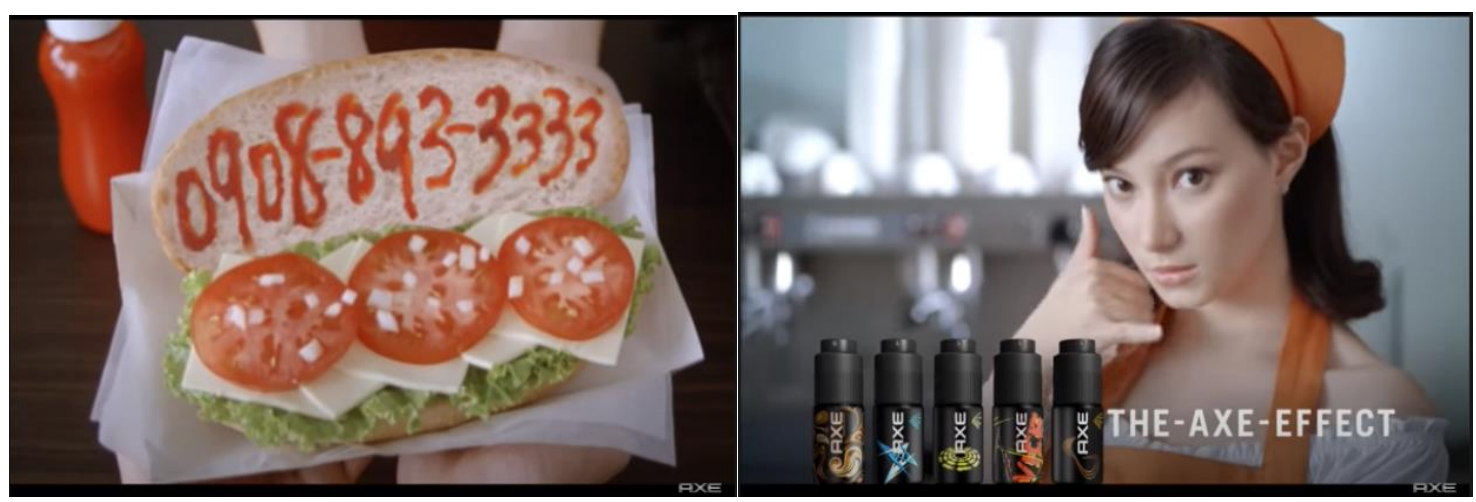

Gambar 3. Iklan Axe Effect Call Me versi Sauce (Youtube)

Makna Denotasi, penanda terakhir pada pada iklan Axe Effect Call Me versi Sauce adalah perempuan yang memberi nomor telpon dan di akhiri dengan adegan perempuan memberi kode untuk 
menghubunginya nanti dengan ekspresi dan tatapan yang menawarkan sensualitas. Ditambah pada bagian akhir iklan ini terdapat pesan "The Axe Effect"

Makna Konotasi, laki-laki menjadi pesona setelah memakai parfum Axe. Scene akhir pada iklan ini menunjukan dimana perempuan itu memberi nomer telpon kepada laki laki melalui sandwich yang dituliskan menggunakan saos pada scene sebelumnya dan bagian akhir pada iklan ini memperlihatkan pesan yaitu "The Axe Effect" dimana pesan ini mempunyai maksud yaitu audiens menerima efek setelah pemakaian parfum Axe. Efek yang di maksud adalah audiens menjadi pesona bagi para perempuan dan audiens akan mudah untuk mendekati lawan jenis hanya dengan menggunakan parfum Axe.

Mitos, pesan yang digunakan dalam iklan Axe "The Axe Effect" merupakan salah satu bentuk pemilihan kata yang di mana kebanyakan laki-laki menginginkan mudahnya mendapatkan kekasih yang pada realitanya para laki-laki merasa sulit mendapatkan kekasih. Hal ini tentu saja membuat banyak laki-laki tertarik utuk memakai parfum Axe. Pada scene akhir memperlihatkan perempuan yang diminta dihubungi setelah memberikan nomer telponnya. Melalui bahasa tubuh (gesture-nya), ekspresi, sikap, dan tingkah laku. Akting lelaki dalam iklan Axe tersebut mengekspresikan rasa kepasrahan menerima semua perlakuan agresif dan berlebihan dari para perempuan yang mengaguminya. Perilaku agresif para perempuan dalam iklan Axe tersebut merupakan efek dari Axe yang dipakai para lelaki. Iklan ini jelas mempresentasikan kesan sensualitas dari perempuan untuk menghasilkan keuntungan. Karena perempuan mempunyai peran sangat besar dalam bahasa media yang dipercaya mampu menguatkan pesan iklan.

\section{PEMBAHASAN}

Kehidupan masyarakat tidak terlepas dari iklan. Iklan selalu mendominasi semua media, mulai dari televisi, radio, koran, hingga media digital. Iklan dibuat semenarik mungkin agar mendapatkan perhatian dari para target audiens. Para pengiklan ingin iklan yang dibuat mendapatkan perhatian paling banyak. Hal ini sering dilakukan dengan memilih model iklan. Perempuan yang menjadi model iklan dianggap mampu menarik perhatian para target audiens. Apabila wanita dan iklan berfungsi sebagai alat berdagang, maka perdagangan berlaku padanya (Hermawan \& Hamzah, 2017).

Eksploitasi perempuan melalui iklan parfum Axe dapat dilihat bahwa citra perempuan yang dapat dikatakan mengalami perkembangan dalam hal elaborasi bentuk, detail teknis, tentu dibantu oleh kemajuan teknologi, sehingga jauh lebih canggih. Iklan sekarang tampak lebih jelas, mengkilap dan menyilaukan mata, tapi cara pikirnya belum banyak berubah, masih patriarkhis-tradisional. Citra perempuan pada saat ini sudah berubah dengan saat dulu. Jika dulunya perempuan Indonesia memilki citra yang berpendidikan, berbudi mulia dan yang memiliki budaya malu tinggi sekarang ini sudah tergantikan oleh karakter yang menghancurkan.

Pada iklan ini menampilkan endorser perempuan dan endorser laki- laki sebagai tokoh dalam visualisasi iklannya. Endorser utama laki-laki selalu sebagai pemakai produk Axe Deodorant Bodyspray. Endorser perempuan memerankan sebagai orang-orang yang tertarik kepada endorser laki-laki karena efek bau Axe Deodorant Bodyspray yang dipakainya. Oleh karena itu, endorser laki-laki selalu mendapatkan simpati dari para perempuan yang ditemuinya. Rasa simpati perempuan-perempuan dalam iklan tersebut divisualisasikan melalui bahasa tubuh (gesture-nya), ekspresi, sikap, dan tingkah laku. Akting laki-laki dalam iklan Axe tersebut mengekspresikan rasa kepasrahan menerima semua perlakuan agresif dan berlebihan dari para perempuan yang mengaguminya. Perilaku agresif para perempuan dalam iklan Axe tersebut merupakan efek dari Axe Deodorant Bodyspray yang dipakai para lelaki. Maka dalam iklan ini sangat terasa didominasi oleh peran endorser perempuan.

Praktek penandaan yang ada dalam iklan ini menunjukan adanya oposisi biner sebagai berikut: 
Tabel 1. Oposisi Biner dalam iklan Axe Effect Call Me versi Sauce

\begin{tabular}{ll}
\hline Tubuh Perempuan Ideal & Tubuh Perempuan Tidak Ideal \\
\hline Langsing & Berisi \\
\hline Padat & Berlemak \\
\hline Berpakaian dengan belahan dada terbuka & Berpakaian tertutup \\
\hline Kulit putih & Kulit non putih \\
\hline Rambut hitam & Rambut tidak hitam \\
\hline
\end{tabular}

Iklan ini jelas menimbulkan citra pigura dan citra peraduan pada perempuan. Citra pigura adalah citra yang menempatkan fisik perempuan sebagai sosok yang cantik, berambut panjang, lembut, dan berbagai sifat feminin lainnya dan Citra pergaulan adalah citra yang menampilkan perempuan sebagai sosok yang cantik, menarik dan anggun sehingga pantas sebagai sosok yang pantas dihormati dalam pergaulan. (Mukti et al., 2015)

Citra pigura terlihat dari kecantikan wajah, kemolekan tubuh, dan tampilan fisik yang menarik. Sementara, citra peraduan terlihat dari bahasa tubuh yang sensual dengan busana yang umumnya ketat dan terbuka. Visualisasi iklan Axe ini merupakan bagian dari rangkaian positioning product (posisi produk), yaitu komunikasi pemasaran, pemilihan strategi kreatif dan media, visualisasi iklan Axe termasuk pertimbangan dipresentasikannya peran dominan perempuan dalam tayangannya.

Representasi seperti ini juga dinamakan Fethistic scopophilia, yaitu menampilkan perempuan cantik sebagai obyek dan ditampilkan sekaligus kepada pelakon laki-laki dan juga kepada penonton, ketika tubuh perempuan di representasikan hanya sebagai obyek dalam sebuah tontonan. Lagi-lagi ini adalah cara representasi diperuntukkan bagi lakon laki-laki dalam filem dan para laki-laki penonton film, si pemeran perempuan dipertontonkan untuk mereka (Rose, 2001).

Sebuah penelitian yang dilakukan oleh Rizki Fitriana, ia menyebutkan bahwa representasi perempuan yang dilakukan oleh pengiklan, masih melekatkan sosok perempuan dengan sensualitas. Pengiklan melakukan berbagai komodifikasi terhadap tubuh perempuan di dalam iklan AXE versi "Bidadari Jatuh", "Polisi Wanita vs Perampok", serta "Pemadam Kebakaran dan Astronot" melalui berbagai atribut yang ditempelkan kepadanya. Sensualitas ini muncul dari atribut-atribut yang dilekatkan pada body images perempuan yang meliputi pakaian yang dikenakan. Sosok perempuan yang dihadirkan di dalam masingmasing iklan tersebut seakan semakin memantapkan asumsi bahwa perempuan memiliki citra peraduan, yakni sosoknya yang dinilai hadir sebatas sebagai objek pemuas hasrat seksual laki-laki. Pengiklan memanfaatkan sosok perempuan dengan melakukan komodifikasi-komodifikasi melalui body images yang tampak. Body images yang tampak merupakan hasil dari seleksi-seleksi yang dilakukan oleh sang pengiklan dalam rangka usahanya membentuk konsep sensualitas (Fitriana, 2005).

Hampir sama seperti penelitian yang dilakukan oleh Rizki Fitriana, penelitian yang kami lakukan memunculkan hasil temuan dimana figur perempuan cenderung tereduksi martabatnya karena tingkah lakunya terutama dari segi pakaian yang ia kenakan serta gerakan gesture yang ditampilkan. Hal ini tentu saja suatu perbuatan yang melanggar etika moral masyarakat, melanggar standar etika periklanan di Indonesia, hingga dapat dikategorikan melanggar etika hukum karena adegan pornoaksi di dalam iklan tersebut. Selanjutnya seks dimunculkan sebagai sesuatu hal yang paling utama dalam suatu hubungan, dan kehebatan hubungan itu kemudian dihubungkan dengan kemampuan produk Axe untuk menarik dan meningkatkan gairah sensualitas yang membuat para laki-laki menjadi pesona para perempuan. Ungkapan verbal dalam iklan tersebut mengandung makna konotasi yang tidak layak untuk disampaikan di ruang publik. Hal ini tentu saja telah mengesampingkan etika dalam mempromosikan produk. 


\section{KESIMPULAN}

Makna representasi sensualitas perempuan dalam iklan parfum Axe versi Sauce terkait makna denotasi yakni berupa representasi sensualitas perempuan yang negatif. Melalui tanda-tanda yang terdapat dalam iklan ini menunjukkan bagaimana eksploitasi terhadap tubuh perempuan. Perempuan hanya dijadikan sebagai objek pandangan bagi kaum laki-laki. Makna representasi sensualitas perempuan dalam iklan parfum Axe versi Sauce terkait makna konotasi yakni berupa representasi sensualitas perempuan yang negatif. Melalui makna di dalam iklan dengan memperlihatkan perempuan menampilkan ekspresi, sikap, gerak-gerik yang menawarkan sensualitas/seksualitas untuk memicu imajinasi seksual pada laki-laki. Makna representasi sensualitas perempuan dalam iklan parfum Axe versi Sauce terkait mitos yakni berupa representasi sensualitas perempuan yang negatif. Melalui pesan dengan bentuk pemilihan kata bahwa kebanyakan laki-laki menginginkan mudahnya mendapatkan kekasih, padahal realitanya para laki-laki sering merasa sulit mendapatkan kekasih. Maka perilaku agresif perempuan dalam iklan ini menimbulkan kesan sensualitas dari perempuan untuk menghasilkan keuntungan. Karena perempuan mempunyai peran yang besar dan dipercaya mampu menguatkan pesan iklan.

\section{PERSANTUNAN}

Terima kasih kepada Dr. Fajar Junaedi yang telah membimbing proses riset dalam mata kuliah Kajian Kritis Iklan di Program Studi Ilmu Komunikasi UMY, selama satu semester genap tahun akademik 2020/2021 yang menghasilkan luaran berupa artikel ini.

\section{REFERENSI}

Alva Orlandini, H. (2003). Bibioteca Hombres del Perú. Vol. 1. https://books.google.com.pe/books?id=iOJyAiS2gG0C\&dq

Fitriana, R. (2005). Perempuan dan Sensualitas: Bentuk Komudifikasi tubuh Perempuan melalui Body Image yang Dikonstruksikan Didalam Iklan EXE. Jurnal Unair, 1(2).

Hall, S. (2003). Representation_Cultural_Representat.pdf.

Hartley, J. (2003). A short history of cultural studies. A Short History of Cultural Studies, 1-189. https://doi.org/10.4135/9781446216934

Hermawan, H., \& Hamzah, R. E. (2017). Objektifikasi Perempuan dalam Iklan Televisi : Analisis Lintas Budaya terhadap Iklan Parfum Axe yang Tayang di Televisi Indonesia dan Amerika Serikat. Jurnal Kajian Media, 1(2), 166-176. https://doi.org/10.25139/jkm.v1i2.721

Laughey, D. (2007). Key themes in media theory. Key Themes in Media Theory, 1-29.

Madina, I. H., \& Kumala, A. D. (2020). Eksploitasi Sensualitas Tubuh Perempuan dalam Iklan Cat Avian Versi Awas Cat Basah. Jurnal Audiens, 1(2). https://doi.org/10.18196/ja.12020

Mukti, I., Sultan, M. I., \& Bahfiarti, T. (2015). Semiotika Ikon Perempuan Pada Iklan Mobil Dalam Majalah Otomotif Autoexpert. Komunikasi KAREBA, 4(3), 344-359.

Nyoman, N., Dyah, I., Luh, N., Purnawan, R., \& Pradipta, A. D. (1992). Representasi perempuan dalam iklan susu jahe sido muncul versi sido susu.

Pah, J. J. (2018). Mitos Seksualitas Dalam Iklan. Nyimak (Journal of Communication), 2(1), 1-16. https://doi.org/10.31000/nyimak.v2i1.723

Pattana Kitiarsa. (2007). Religious Commodifications in Asia: Marketing Gods.

Raturahmi, L., \& Wanty, F. (2015). Representasi Sensualitas Perempuan Dalam Iklan Parfum Axe. Jurnal Komunikasi Hasil Pemikiran Dan Penelitian, 1(2), 66-77.

https://journal.uniga.ac.id/index.php/JK/article/view/533

Rose, Gillian. (2001). Visual Methodologies. 
Scott, J. W. (1997). Oxford Readings in Feminism: Feminism \& History. Feminism $\mathcal{E}$ History, 1-16. Shimp, Terence A. (2003). Periklanan Promosi (Jilid 1). Jakarta: Erlangga

Wibowo, I. S. W. (2013). Semiotika komunikasi. In ウイルス.

Zein, M. (2015) Periklanan Sebuah Pendekatan Praktis. Yogyakarta. Buku Litera. 